\title{
Investigation of the Anisotropic Structure of Travertine in Terms of Geological and Physico-Mechanical Properties: Sarıhıdır (Avanos-Nevşehir) Travertine Quarry
}

Ersin Kolay ( $\nabla$ ersin.kolay@bozok.edu.tr)

Yozgat Bozok Universitesi

Gökhan Karakoç

Yozgat Municipality

Uğur Temiz

Yozgat Bozok Universitesi

Research Article

Keywords: Anisotropy, natural stone, physico-mechanical properties, Sarıhıdır, travertine

Posted Date: January 11th, 2022

DOl: https://doi.org/10.21203/rs.3.rs-1177655/v1

License: (c) (i) This work is licensed under a Creative Commons Attribution 4.0 International License. Read Full License 


\section{Abstract}

Travertine is a sedimentary rock with generally layered structure, mainly comprising carbonate. They are used for different purposes in interior and exterior spaces by cutting parallel or perpendicular to the bedding according to use. Travertine may contain several facies linked to variations in conditions during formation. With these features, travertine is one of the rocks with anisotropy most commonly observed. In this study, the anisotropic structure due to facies and layering in travertine was investigated considering geological and engineering properties. The Sarıhıdır travertine quarry face was divided into four different zones with different features. Chemical, mineralogic, physical, index and mechanical properties of the samples taken from these zones were determined. During determination of engineering parameters, samples were prepared parallel and perpendicular to bedding. The source of the travertine is a mixture of limestone, dolomite, evaporite and ultramafic rocks and they have epigean character, though they were affected by the hypogean environment. It appeared there were textural differences between the zones, rather than differences in chemical and mineralogic composition. When travertine was cut parallel to layering, all zones were suitable for decoration and facing. Only T-4 zone samples cut parallel were useable for flooring and load-bearing elements. In terms of compression and abrasion resistance, $\mathrm{T}-4$ zone was better than the other zones. The cut direction of the travertine samples is an important factor for physical and mechanical behavior. Samples cut parallel to layering were observed to provide better results. According to the results, it is recommended to use products from the same travertine zone sideby-side in structures and to consider the cutting direction for long life of the building and to prevent economic losses.

\section{Introduction}

Travertine has been used as facing, flooring and load-bearing elements in buildings from past to present due to features like being suitable for cutting and polishing, being porous and light, and having different color tones. The name travertine comes from the Tibur near Rome and the rock was called Lapis Tiburtinus in ancient times (Altunel, 1996). Travertine is a carbonate sedimentary rock comprising mainly calcite and aragonite precipitated in terrestrial environments (Pentecost, 2005). Travertine was defined as freshwater carbonates precipitated by organic and inorganic processes by Chafetz and Folk (1984). The formation model for travertine of İnan (1985) explained the process as enrichment of water contained in calcareous and marble rocks with carbon dioxide to create carbonic acid $\left(\mathrm{H}_{2} \mathrm{CO}_{3}\right)$ which increases the solvent features of the water (Eq. 1). As these waters containing carbonic acid circulate in carbonate rocks, they dissolve calcium carbonate and become enriched with calcium bicarbonate $\left(\mathrm{Ca}\left(\mathrm{HCO}_{3}\right)_{2}\right)\left(\mathrm{Eq}^{2} \mathrm{2}_{2}\right)$. When the waters rich in calcium bicarbonate reach the surface, carbon dioxide evaporates linked to varying temperature and pressure conditions and secondary calcium carbonate is precipitated (Eq. 3). Travertine may form in cold and hot springs. In hot springs, the temperature is generally around $36-37^{\circ} \mathrm{C}$ (Atiker, 1993). In the literature, travertine is classified based on morphology (Altunel, 1996) and lithotype (Guo and Riding, 1998). While the morphologic characteristics of travertine are important for touristic purposes, chemical and mechanical characteristics are important for use for industrial purposes (Wilson, 1979; Chafetz and Folk, 1984).

$\mathrm{H}_{2} \mathrm{O}+\mathrm{CO}_{2} \rightarrow \mathrm{H}_{2} \mathrm{CO}_{3}(1)$

$\mathrm{H}_{2} \mathrm{CO}_{3}+\mathrm{CaCO}_{3} \rightarrow \mathrm{Ca}\left(\mathrm{HCO}_{3}\right)_{2}(2)$

$\mathrm{Ca}\left(\mathrm{HCO}_{3}\right)_{2} \rightarrow \mathrm{CaCO}_{3} \downarrow+\mathrm{H}_{2} \mathrm{O}+\mathrm{CO}_{2} \uparrow(3)$

Travertine is natural stones used in many important buildings in countries like Italy, Turkey, Hungary, and the United States of America. Currently, Turkey is one of the most important suppliers of the world travertine market. The travertine reserve in Turkey is stated to be nearly $1 \times 109 \mathrm{~m}^{3}$ (Altunel and Hancock, 1983; Tutuş, 2009). Gökçe (2014) stated there 
were 8 different types of travertine formations in Turkey, classified morphologically as terraced-mound type, fissureridge type, dome type, layered type, vein type, range front type, self-built channel travertine, and cave type. Nevşehir is an important region in Turkey in terms of travertine, with travertine formations located in Avanos (Sarıhıdır, Salanda and Karakaya) and Kozaklı counties (Bolat, 2011).

Travertine attracted the interest of the construction sector during history and is the subject of many studies in the literature due to their use in buildings. Uz et al. (2001) investigated the geological, petrographic, physical and mechanical properties of travertine from Bartın (Turkey) and assessed them for possibility of use as marble. Török and Vásárhelyi (2010) investigated some physical and mechanical properties under dry and saturated conditions for massive and laminated cavity travertine selected from Hungary. Gökçe et al. (2016) used basic experimental methods to investigate the effect of freeze-thaw on travertine used in historical structures in Konya (Turkey). García-del-Cura et al. (2012) investigated sedimentary structures and physical features of travertine and revealed the rock anisotropy with ultrasonic P-wave measurements. Many researchers investigated the effect of filling pores in travertine with chemical agents on physical, mechanical and technological properties (Acar, 2003; Demirdag, 2009-2013; Isık and Ozkahraman, 2010). Sengun et al. (2015) investigated the variation in physical and mechanical features by exposing travertine samples cut in different directions to freeze-thaw and thermal shock cycles.

Travertine may have a complicated internal structure linked to many factors like the location of the source, basal topography, chemical composition of waters forming travertine, organic activity and status of surface waters (Kaplan, 2010; Gökçe, 2014), so a travertine block may contain many facies (García-del-Cura et al., 2012). The methode of the cut in travertine is generally determined linked to the architectural design. In industrial applications, cut parallel to layering is called "normal cut", while cut perpendicular to layering is called "American cut". Travertine may have very different appearances linked to the cut direction (Gökçe, 2014). When travertine is crosscut (American cut), the natural cavities, channels and veins of the travertine emerge, while parallel (vein) cut hides these features (Chin, 2007). Some researchers investigated the effect of cut direction on the engineering properties of travertine (Çobanoğlu and Çelik, 2012; Ayaz and Karacan, 2000; Gökçe, 2014). Çobanoğlu and Çelik (2012) stated that travertine is a very heterogeneous rock due to the naturally-occurring cavities, channels and bedded structure. For this reason, they stated there may be variability in features like uniaxial compressive strength, flexural strength and unit weight in the same production region, or even in the same quarry. Ozcelik and Yilmazkaya (2011) and Ersoy et al. (2005) stated that diamond wire cutting was affected by anisotropy due to bedding and that cuts parallel to the bedding plane were more economic.

As mentioned above, travertine has very complicated anisotropic structure due to their formation and this may even be observed at the centimeter scale. Thus, travertine products produced from the same block may have very different visual, physical and mechanical properties. These differences may negatively affect the building lifetime of the product or require occasional repairs. Within the scope of this study, four zones were determined in the Sarıhıdır (Nevşehir) travertine area by noting features like color, porosity and banding and the geological, physical and mechanical properties of these zones were investigated paying attention to bedding. The study aimed to reveal the anisotropic status emerging both between zones and according to the cut direction within the zones. The results obtained from the study were evaluated by comparing the results of previous studies in the literature. This study will be the first to examine a travertine quarry in facies dimension.

\section{Geological Setting of Travertine Field}

The study area is located nearly $98 \mathrm{~km}$ northeast of Avanos in a region known as the Central Anatolia Volcanic Province (Fig. 1). The basement of the study area comprises granitic rocks outcropping to the north. The age of these rocks was given as Paleocene by Seymen (1981) and Upper Cretaceous by Ataman (1972). Cover units overlie the 
basement units above an unconformity. The cover units begin with a unit comprising Upper Miocene-Pliocene finebedded and laminated siltstone, silicic claystone, laminated sandstone and tuffite intercalations (Atabey et al., 1988). Above this unit, Upper Miocene-Pliocene white, gray and yellow tuffites outcrop. At the top, Quaternary units outcrop with an unconformity. The south of the study area comprises pebbles and poorly consolidated sandstone (Atabey, 1989). In the study area, units comprising conglomerate, sandstone and clay outcrop along the Kızılırmak River. Additionally, current alluvium sediments comprise gravel, sand, clay and soil observed along the Kızılırmak River and tributaries (Atabey, 1989).

The Late Pleistocene-Holocene Sarıhıdır travertine, forming the topic of the study (Fig. 2), comprise a region with 0.3-1 km width, 6.5 km length and NNE strike north of Sarıhıdır village (Koçyiğit and Doğan, 2016). Sarıhıdır travertine comprises fissure-ridge type travertine and was associated with the Salanda Fault by Koçyiğit and Doğan (2016). The travertine in the field is laminated; with lamina thickness varying from several milimeters to several cantimeters. Additionally irregular macro cavities are observed. According to U/Th age dating of this travertine, age dates of nearly 50-53 ka years were obtained (Koçak, 2020).

\section{Petrographical and chemical investigations}

In field studies, travertine samples were divided into four zones based on features like lithology, color differences, porosity, bedding, etc. (Fig. 3) and these zones were named T-1, T-2, T-3 and T-4. The thickness of these zones varies from a few centimeters to a few meters on the nearly $7 \mathrm{~m}$-high quarry face. T- 1 and T-2 zones are laminated, while T-3 and T-4 zones are dominated by banded structure. Thin section investigations to determine the mineralogic and textural properties of the travertine zones were completed with a polarizing microscope and photographs were taken (Fig. 4). For mineralogical composition, XRD was also performed. According to petrographic investigation and XRD analysis, travertine zones were understood to have similar mineralogic composition. T-1 group travertine dominantly comprises calcite with comb and conchoidal texture, with lower amounts of aragonite. Large calcite crystals represent precipitation in a relatively stagnant environment. Iron and manganese opaque minerals are located between the bands. From XRD analysis, the opaque minerals were identified as pyrolusite, rhodochrosite and goethite. T-2 zone appears to have variable porosity, with large and small crystals observed together linked to water flow. The rock contains small amounts of clay, chalcedony and aragonite. T-3 zone has clear banded texture occurring due to micritic and sparitic calcite and has a slight green color in hand sample. This indicates rapid variation in the flow of the solutions entering the environment. T-3 zone is understood to contain higher amounts of clay minerals, different to the other zones. T-4 zone travertine is generally brown color, with banded structure caused by comb-texture calcite and micritic calcite sludge (Fig. 4). Dissolution and gas cavities extend parallel to bedding and are irregular. Prepared thin sections observed stalagmitic texture in levels following fine carbonate laminations determined with different colors and thicknesses in the travertine formation in the field. Acicular fibers and undulating prismatic crystals comprise a succession of intercalated sequences and intercalations of micrite and sparite bands are observed in thin sections. Acicular fibers are generally dark brown with micritic character on petrographic investigations, while large prismatic crystals have white color under single polarizer (Nicol) and typical interference colors for calcite under cross-polarized light (crossed Nicol). Quartz (opal) and aragonite minerals detected in XRD analyses were not identified during petrographic investigations. For this reason, these minerals may be found in micritic zones with acicular texture.

The chemical compositions of three samples from each travertine zone determined in the field were investigated with $\mathrm{x}$ ray fluorescence spectrometry (XRF) and mean values are given in Fig. 5. If the $\mathrm{CaO}$ value is high in the travertine, the travertine has a white color and its hardness does not vary much. In travertine, $\mathrm{SiO}_{2}$ and $\mathrm{Al}_{2} \mathrm{O}_{3}$ affect hardness, while $\mathrm{Fe}_{2} \mathrm{O}_{3}$ affects color. Increased $\mathrm{Fe}_{2} \mathrm{O}_{3}$ values cause the color of travertine to vary from light yellow to brown and red. $\mathrm{MgO}$ emerges in the association of travertine with basic-ultrabasic rocks, and though low in amount, it increases 
hardness. High $\mathrm{Na}$ and $\mathrm{K}$ elements cause travertine to appear green (Ayaz, 2002). The similarity of CaO values in the mineralogic composition of travertine zones in the study area appears to support their similarities. $\mathrm{MnO}$ and $\mathrm{SO}_{3}$ values are high in $\mathrm{T}-1$ zone. It is understood that hydrothermal solutions brought $\mathrm{Mn}$ and $\mathrm{S}$ to the environment during formation of $\mathrm{T}-1$ zone. $\mathrm{K}_{2} \mathrm{O}, \mathrm{SiO}_{2}$ and $\mathrm{Al}_{2} \mathrm{O}_{3}$ values are clearly elevated in $\mathrm{T}-3$ zone, indicating argillization in this zone. Additionally, high $\mathrm{K}_{2} \mathrm{O}$ gives T-3 zone a greenish color. LOI values are partly high in T-1 and T-2 zones, leading to consideration that these zones contain more organic material compared to other zones. Interaction of hydrothermal solutions with wall rocks is an important process in travertine formation. The Ba-Sr graph provides information about the source and hydrological regime in travertine (Teboul et al., 2016). The Sr and Ba contents of travertine samples were between 594.20-2101.00 ppm and 70.90-563.10 ppm, respectively, which is very high. These values prove that travertine (calcitic or aragonitic travertine and tufa, CATT) was associated with ultramafic sources. Additionally, when the distribution of samples on Fig. 6 is investigated, the source rock may be said to be a mix of limestone, dolomite and evaporite. On the Ba-Sr graph, all T-1 and T-3 samples and one of the T-4 samples were close to the epigean field, while all T-2 samples were close to the hypogean field. Accordingly, it is considered that the travertine in the study area have epigean character; however, they were affected by the hypogean environment.

\section{Material And Method}

With the aim of determining physical and mechanical properties, cube samples with dimensions of $22 \times 22 \times 22 \mathrm{~cm}$ were obtained from zones identified in the travertine quarry in the field. From these cubes, cylindrical samples were prepared for uniaxial compressive strength (UCS) experiments according to ASTM (2002). During the sample preparation process, the core axis was placed in parallel $(/ /)$ and perpendicular $(\perp)$ to bedding to determine anisotropic behavior due to bedding (Fig. 7). The number of samples chosen for each zone was 36, with 18 parallel to bedding and 18 perpendicular to bedding. Density $(\rho)$, apparent porosity $(n)$, water absorption by weight $\left(A_{w}\right)$, ultrasound velocity $\left(V_{p}\right)$

and point load strength index $\left(\mathrm{I}_{\mathrm{s}(50)}\right)$ experiments performed by using prismatic samples according to ISRM (2007). For point load strength index experiments, 5 samples were used with loading perpendicular and parallel to bedding in each zone. Of the samples for each zone, 16 (8 perpendicular, 8 parallel) were used for freeze-thaw experiments. The freezethaw experiments were applied with 30 cycles of $-12{ }^{\circ} \mathrm{C}$ freezing and $+20{ }^{\circ} \mathrm{C}$ thawing as stated in TSE EN 12371 (TSE, 2011). The Los Angeles abrasion resistance (LA) was determined according to ASTM (2006) for each zone. The Böhme abrasion losses (BAL) for the travertine zones were determined according to TS EN 14157 (TSE, 2017) with the abrasion plates placed perpendicular and parallel to bedding surfaces of the samples. In this experiment, 3 samples were used for each zone and the average was calculated.

\section{Results And Discussion}

The physical, index and mechanical properties of travertine according to zone are summarized in Tables 1 and 2 . In the literature, rocks are classified according to some physical, index and mechanical properties. These may be listed as porosity, uniaxial compressive strength, point load strength index and ultrasound velocity (Table 3 ). 
Table 1

Physical and mechanical features of travertine zones

\begin{tabular}{|c|c|c|c|c|c|c|c|c|}
\hline Zone/Direction & $\begin{array}{l}\text { Number of } \\
\text { samples }\end{array}$ & & $\begin{array}{l}\rho_{d} \\
\left(\mathrm{~g} / \mathrm{cm}^{3}\right)\end{array}$ & $\begin{array}{l}\rho_{\text {sat }} \\
\left(\mathrm{g} / \mathrm{cm}^{3}\right)\end{array}$ & n (\%) & $\begin{array}{l}A_{w} \\
(\%)\end{array}$ & $\begin{array}{l}V_{p} \\
(m / s)\end{array}$ & $\begin{array}{l}\text { UCS } \\
\text { (MPa) }\end{array}$ \\
\hline \multirow[t]{4}{*}{$\mathrm{T}-1(/ /)$} & \multirow[t]{4}{*}{10} & Max. & 2.60 & 2.62 & 4.39 & 1.73 & 5665 & 42 \\
\hline & & Min. & 2.49 & 2.53 & 1.89 & 0.73 & 4611 & 19 \\
\hline & & Avg. & 2.56 & 2.59 & 2.91 & 1.22 & 5139 & 31 \\
\hline & & Sdev. & 0.03 & 0.03 & 0.86 & 0.35 & 324 & 7 \\
\hline \multirow[t]{4}{*}{$\mathrm{T}-1(\perp)}$. & \multirow[t]{4}{*}{10} & Max. & 2.62 & 2.63 & 11.51 & 5.28 & 5655 & 47 \\
\hline & & Min. & 2.32 & 2.44 & 0.99 & 0.38 & 3760 & 14 \\
\hline & & Avg. & 2.51 & 2.55 & 5.46 & 2.45 & 4460 & 28 \\
\hline & & Sdev. & 0.09 & 0.06 & 3.18 & 1.52 & 775 & 10 \\
\hline \multirow[t]{4}{*}{ T-2/Par. } & \multirow[t]{4}{*}{10} & Max. & 2.63 & 2.65 & 6.01 & 2.89 & 4747 & 41 \\
\hline & & Min. & 2.31 & 2.40 & 1.57 & 0.62 & 3810 & 21 \\
\hline & & Avg. & 2.54 & 2.57 & 2.49 & 1.06 & 4420 & 32 \\
\hline & & Sdev. & 0.09 & 0.07 & 1.45 & 0.70 & 260 & 8 \\
\hline \multirow[t]{4}{*}{ T-2/Per. } & \multirow[t]{4}{*}{10} & Max. & 2.57 & 2.59 & 2.76 & 1.20 & 4322 & 33 \\
\hline & & Min. & 2.53 & 2.55 & 2.05 & 0.80 & 3296 & 17 \\
\hline & & Avg. & 2.55 & 2.57 & 2.44 & 0.97 & 3897 & 24 \\
\hline & & Sdev. & 0.01 & 0.01 & 0.21 & 0.11 & 387 & 6 \\
\hline \multirow[t]{4}{*}{ T-3/Par. } & \multirow[t]{4}{*}{10} & Max. & 2.62 & 2.64 & 1.93 & 0.75 & 5718 & 41 \\
\hline & & Min. & 2.57 & 2.59 & 1.48 & 0.56 & 4800 & 23 \\
\hline & & Avg. & 2.60 & 2.61 & 1.66 & 0.65 & 5216 & 31 \\
\hline & & Sdev. & 0.02 & 0.02 & 0.16 & 0.07 & 302 & 6 \\
\hline \multirow[t]{4}{*}{ T-3/Per. } & \multirow[t]{4}{*}{10} & Max. & 2.60 & 2.63 & 4.13 & 1.66 & 4623 & 42 \\
\hline & & Min. & 2.46 & 2.50 & 2.03 & 0.78 & 3350 & 15 \\
\hline & & Avg. & 2.54 & 2.57 & 2.89 & 1.12 & 3871 & 24 \\
\hline & & Sdev. & 0.05 & 0.04 & 0.61 & 0.25 & 449 & 8 \\
\hline \multirow[t]{4}{*}{ T-4/Par. } & \multirow[t]{4}{*}{10} & Max. & 2.58 & 2.60 & 10.90 & 4.70 & 5740 & 56 \\
\hline & & Min. & 2.32 & 2.43 & 2.06 & 0.80 & 4874 & 29 \\
\hline & & Avg. & 2.46 & 2.51 & 5.20 & 2.25 & 5368 & 42 \\
\hline & & Sdev. & 0.09 & 0.06 & 2.81 & 1.22 & 313 & 10 \\
\hline \multirow[t]{2}{*}{ T-4/Per. } & \multirow[t]{2}{*}{10} & Max. & 2.59 & 2.61 & 6.23 & 2.65 & 5141 & 43 \\
\hline & & Min. & 2.35 & 2.41 & 2.29 & 0.88 & 3610 & 20 \\
\hline
\end{tabular}




\begin{tabular}{lllllll|} 
Avg. & 2.48 & 2.52 & 4.05 & 1.65 & 4558 & 32 \\
\hline Sdev. & 0.07 & 0.06 & 1.11 & 0.50 & 665 & 8 \\
\hline
\end{tabular}

Table 2

Values for Los Angeles abrasion loss at 100 cycles $\left(\mathrm{LA}_{100}\right)$ and 500 cycles $\left(\mathrm{LA}_{500}\right)$, point load strength index $\left(\mathrm{I}_{\mathrm{s}(50)}\right)$ and Böhme abrasion loss values (BAL) for travertine groups

\begin{tabular}{|c|c|c|c|c|c|c|c|}
\hline Zone & $\begin{array}{l}\mathrm{LA}_{100} \\
(\%)\end{array}$ & $\begin{array}{l}\mathrm{LA}_{500} \\
(\%)\end{array}$ & $\begin{array}{l}\text { Don kaybı } \\
\text { (30 cycles) (\%) }\end{array}$ & $\begin{array}{l}\mathrm{BAL}(/ /) \\
\left(\mathrm{cm}^{3} / 50 \mathrm{~cm}^{2}\right)\end{array}$ & $\begin{array}{l}\mathrm{BAL}(\perp) \\
\left(\mathrm{cm}^{3} / 50 \mathrm{~cm}^{2}\right)\end{array}$ & $\begin{array}{l}\mathrm{I}_{\mathrm{s}(50),}(/ /) \\
(\mathrm{MPa})\end{array}$ & $\begin{array}{l}I_{s(50),}(\perp) \\
(M P a)\end{array}$ \\
\hline T-1 & 12 & 48 & 0.06 & 8.96 & 16.14 & 2.52 & 5.89 \\
\hline T-2 & 17 & 65 & 0.04 & 10.97 & 11.04 & 2.61 & 4.59 \\
\hline T-3 & 20 & 49 & 0.07 & 9.58 & 10.00 & 3.97 & 6.27 \\
\hline T-4 & 9 & 36 & 0.04 & 8.96 & 9.34 & 2.25 & 8.41 \\
\hline
\end{tabular}

The apparent porosity of travertine samples was assessed according to the porosity classification of Moos and Quervain (1948). According to the porosity values seen in Table 1, in the T-1 group, parallel samples had less pores, while perpendicular samples had quite pores. In the T-2 group, parallel and perpendicular samples were in the group with less pores. In the T-3 group, the parallel samples had less pores and the perpendicular samples were in the group with moderately pores. For the T-4 group, parallel samples had highly pores and perpendicular samples were in the group with moderately pores. A significant portion of the porosity in travertine formed linked to the degradation of organic matter and release of gases. The main reason the type of cut affected the porosity may be considered to be the lack of connection between the pores. According to Bieniawski's (1975) classification, when the loading direction is parallel to bedding all groups appeared to be in the moderate strength rock class. When the loading direction is perpendicular to the bedding, T-1, T-2 and T-3 were in the high strength class, while T-4 was in the very high strength class. The mean uniaxial compressive strength of samples prepared parallel and perpendicular to bedding of travertine were T-1 zone 30.7 MPa-27.79 MPa, T-2 zone 31.74 MPa-24.28 MPa, T-3 zone 30.54 MPa-24.25 MPa and T-4 zone 41.61 MPa-32.42 MPa, respectively. Nearly all of these values appear to fall in the low strength rock class according to the classification by Deer and Miller (1966) (Table 3). Guo and Riding (1998) stated that travertine may be sensitive and easily fractured when the crystal shell is young. The low UCS values and high abrasion losses for travertine in the study area may be due to being young formations. The ultrasound velocities of travertine (Table 1) were evaluated according to Annon (1979). Accordingly, the velocity values for T-1 and T-4 zones parallel to bedding were very high, while perpendicular to bedding values were high. Velocity values measured parallel and perpendicular to bedding in T-2 zone were in the high class. Velocity measured parallel to bedding in T-3 zone was in the very high class, while velocity measured perpendicular fell into the moderate class. 
Table 3

Classification of rocks according to porosity $(n)$, ultrasound velocity $\left(V_{p}\right)$, point load strength index $\left(\mathrm{I}_{\mathrm{s}(50)}\right)$ and uniaxial compressive strength (UCS)

\begin{tabular}{|c|c|c|c|c|c|c|c|}
\hline \multicolumn{2}{|c|}{$\begin{array}{l}\text { Moos-Quervain } \\
\text { (1948) }\end{array}$} & \multicolumn{2}{|l|}{$\begin{array}{l}\text { Annon } \\
(1979)\end{array}$} & \multicolumn{2}{|l|}{$\begin{array}{l}\text { Bieniawski } \\
\text { (1975) }\end{array}$} & \multicolumn{2}{|c|}{$\begin{array}{l}\text { Deer ve Miller } \\
\text { (1966) }\end{array}$} \\
\hline $\begin{array}{l}\mathrm{n} \\
(\%)\end{array}$ & Description & $\mathrm{V}_{\mathrm{p}}(\mathrm{m} / \mathrm{s})$ & Description & $\begin{array}{l}\mathrm{I}_{\mathrm{S}(50)} \\
(\mathrm{MPa})\end{array}$ & Description & $\begin{array}{l}\text { UCS } \\
\text { (MPa) }\end{array}$ & Description \\
\hline$<1$ & Highly compact & $<2500$ & Very low & $<1$ & $\begin{array}{l}\text { Very low } \\
\text { strength }\end{array}$ & $<25$ & $\begin{array}{l}\text { Very low } \\
\text { strength }\end{array}$ \\
\hline $\begin{array}{l}1- \\
2.5\end{array}$ & Less & $\begin{array}{l}2500- \\
3500\end{array}$ & Low & $1-2$ & Low & $25-50$ & Low \\
\hline & porous & & & & strength & & strength \\
\hline $\begin{array}{l}2.5- \\
5\end{array}$ & $\begin{array}{l}\text { Moderately } \\
\text { porous }\end{array}$ & $\begin{array}{l}3500- \\
4000\end{array}$ & Moderate & $2-4$ & $\begin{array}{l}\text { Moderate } \\
\text { strength }\end{array}$ & $50-100$ & $\begin{array}{l}\text { Moderate } \\
\text { strength }\end{array}$ \\
\hline $5-10$ & $\begin{array}{l}\text { Quite } \\
\text { porous }\end{array}$ & $\begin{array}{l}4000- \\
5000\end{array}$ & High & $4-8$ & $\begin{array}{l}\text { High } \\
\text { strength }\end{array}$ & $100-200$ & $\begin{array}{l}\text { High } \\
\text { strength }\end{array}$ \\
\hline $10-15$ & $\begin{array}{l}\text { Highly } \\
\text { porous }\end{array}$ & $>5000$ & Very high & $>8$ & $\begin{array}{l}\text { Very high } \\
\text { strength }\end{array}$ & $>200$ & $\begin{array}{l}\text { Very high } \\
\text { strength }\end{array}$ \\
\hline$>20$ & $\begin{array}{l}\text { Extremely } \\
\text { porous }\end{array}$ & & & & & & \\
\hline
\end{tabular}

Uniaxial compressive strength leads the list of important engineering parameters for rocks. For this reason, many researchers investigated the correlations between uniaxial compressive strength with other rock properties (Tuğrul and Zarif, 1999; Akesson et al., 2001; Kolay and Başer, 2017; Khanlari and Naseri, 2017). If the uniaxial compressive strength of the rocks is high, it is expected that the porosity will be low, and parameters such as density, point load strength index and ultrasound velocity will be high. For travertine, these relationships were examined with simple regression analyzes by considering the sample cutting direction and summarized in Fig. 8 and Table 4. 
Table 4

Simple regression correlations between UCS values and other rock characteristics of travertine

\begin{tabular}{|c|c|c|c|c|c|}
\hline Zons & Direction & UCS- $\rho_{d}$ & UCS-n & UCS-V $_{p}$ & UCS- $I_{s(50)}$ \\
\hline \multirow[t]{2}{*}{$\mathrm{T}-1$} & $/ /$ & $\begin{array}{l}\text { UCS }=148.86 \rho_{d^{-}}-50.4 \\
r=0.75\end{array}$ & $\begin{array}{l}\text { UCS }=-3.60 n+41.18 \\
r=-0.47\end{array}$ & $\begin{array}{l}\text { UCS }=0.0127 V_{p}-4.73 \\
r=0.63\end{array}$ & $\begin{array}{l}\text { UCS } \\
=5.75 \mathrm{I}_{S(50)}+15.90 \\
r=0.94\end{array}$ \\
\hline & $\perp$ & $\begin{array}{l}\text { UCS }=0.0073 e^{3.2652 p d} \\
r=0.80\end{array}$ & $\begin{array}{l}\text { UCS }=44.274 e^{-} \\
0.096 n \\
r=-0.83\end{array}$ & $\begin{array}{l}\text { UCS }=0.0104 V_{p}-8.48 \\
r=0.81\end{array}$ & $\begin{array}{l}\text { UCS } \\
=14.36 \mathrm{I}_{S(50)}+9.38 \\
r=0.98\end{array}$ \\
\hline \multirow[t]{2}{*}{$\mathrm{T}-2$} & $/ /$ & $\begin{array}{l}\text { UCS }=0.1421 e^{2.1182 \rho d} \\
r=0.73\end{array}$ & $\begin{array}{l}\text { UCS }=-4.24 n+42.08 \\
r=-0.60\end{array}$ & $\begin{array}{l}\text { UCS }=0.02 V_{p}-56.87 \\
r=0.67\end{array}$ & $\begin{array}{l}\text { UCS } \\
=7.31 \mathrm{I}_{\mathrm{S}(50)}+11.18 \\
r=0.93\end{array}$ \\
\hline & $\perp$ & $\begin{array}{l}\text { UCS }=252.57 \rho_{d}-618.51 \\
r=0.58\end{array}$ & $\begin{array}{l}\text { UCS }=-9.4596 \\
n+48.72 \\
r=-0.58\end{array}$ & $\begin{array}{l}\text { UCS }=0.0109 V_{p}-18.28 \\
r=0.77\end{array}$ & $\begin{array}{l}U C S=3.89 \mathrm{I}_{S(50)}+5.71 \\
r=0.97\end{array}$ \\
\hline \multirow[t]{2}{*}{ T-3 } & // & $\begin{array}{l}\text { UCS }=161.35 \rho_{d}-389.54 \\
r=0.62\end{array}$ & $\begin{array}{l}\text { UCS }=75.921 e^{-0.584 x} \\
r=-0.69\end{array}$ & $\begin{array}{l}\text { UCS }=0.0164 V_{p}-55 \\
r=0.89\end{array}$ & $\begin{array}{l}U C S=8.39 \mathrm{I}_{S(50)^{-1.74}} \\
r=0.98\end{array}$ \\
\hline & $\perp$ & $\begin{array}{l}\text { UCS }=137.15 \rho_{d}-323.55 \\
r=0.82\end{array}$ & $\begin{array}{l}\text { UCS }=77.35 n^{-1.161} \\
r=-0.74\end{array}$ & $\begin{array}{l}\text { UCS }=0.0141 V_{p}-30.5 \\
r=0.77\end{array}$ & $\begin{array}{l}\text { UCS }=4.20 \mathrm{I}_{S(50)}+0.20 \\
r=0.99\end{array}$ \\
\hline \multirow[t]{2}{*}{$\mathrm{T}-4$} & // & $\begin{array}{l}\text { UCS }=89.375 \rho_{d^{-}}-178.07 \\
r=0.98\end{array}$ & $\begin{array}{l}\text { UCS }=68.956 n^{-0.35} \\
r=-0.85\end{array}$ & $\begin{array}{l}\text { UCS }=0.0242 V_{p}-88.15 \\
r=0.79\end{array}$ & $\begin{array}{l}\text { UCS }=14.36 \mathrm{I}_{S(50)}+9.38 \\
r=0.98\end{array}$ \\
\hline & $\perp$ & $\begin{array}{l}\text { UCS }=0.067 \rho_{d} 6.7765 \\
r=0.71\end{array}$ & $\begin{array}{l}\text { UCS }=55.619 e^{-0.14 n} \\
r=-0.60\end{array}$ & $\begin{array}{l}U C S=0.0081 V_{p}-4.47 \\
r=0.68\end{array}$ & $\begin{array}{l}\text { UCS }=8.52 I_{S(50)}-39.62 \\
r=0.98\end{array}$ \\
\hline
\end{tabular}

Khanleri and Naseir (2017) investigated different types of travertine cut parallel and perpendicular to bedding using simple regression analysis for UCS and other rock characteristics and found more significant correlations for samples cut parallel (Table 4). Some researchers (Ayaz and Karacan, 2000; García-del-Cura et al., 2012; Çobanoğlu and Çelik, 2012; Chentout et al., 2015) obtained higher uniaxial compressive strength values for travertine when loading direction was parallel to bedding. Ayaz and Karacan (2000) explained that when the loading direction parallel to bedding, laminates act like a load-bearing column. The same study stated that pore lines could not carry adequate compression in load applications perpendicular to bedding and fracture occurred at lower compression. Similarly, Chentout et al. (2015) stated that during fracture of rocks under compression, fractures followed pore openings rather than forming new fractures. In this study, in load conditions parallel and perpendicular to bedding, similar results to those explained above were obtained for travertine from T-2, T-3 and T-4 zones especially (Table 1).

When the point load strength index values of travertine are investigated (Table 2), contrary to UCS values, higher values were obtained with loading perpendicular to bedding, with lower values obtained for parallel loading conditions. Accordingly, it can be said that the bedding surfaces act as renewal surfaces under parallel loading conditions. Many previous studies obtained UCS values indirectly from $\mathrm{I}_{\mathrm{s}(50)}$ values with the aid of a conversion factor (K) (Eq. 4) (Broch and Franklin, 1972; Bieniawski, 1975; Kahraman, 2009). In the literature, conversion factors vary from nearly 4 to 29 
according to rock type. In this study, conversion factors varying from 8-19 and 4-5 were obtained for loading conditions parallel and perpendicular to bedding, respectively (Table 5).

$\mathrm{UCS}=\mathrm{K} . \mathrm{I}_{\mathrm{s}(50)}(4)$

Table 5

Conversion factors $(\mathrm{K})$ for travertine between UCS and $\mathrm{I}_{\mathrm{s}(50)}$ according to loading directions

\begin{tabular}{|lllll|}
\hline Travertine & Load direction & UCS & $\mathrm{I}_{\mathbf{s}(50)}$ & $\mathrm{K}$ \\
\hline T1 & $/ /$ & 31 & 2.52 & 12 \\
\cline { 2 - 5 } & $\perp$ & 28 & 5.89 & 5 \\
\hline T2 & $/ /$ & 32 & 2.61 & 12 \\
& $\perp$ & 24 & 4.59 & 5 \\
\hline T3 & $/ /$ & 31 & 3.97 & 8 \\
& $\perp$ & 24 & 6.27 & 4 \\
\hline T4 & $/ /$ & 42 & 2.25 & 19 \\
& $\perp$ & 32 & 8.41 & 4 \\
\hline
\end{tabular}

The increase in porosity is stated to lower the P-wave velocity in travertine in many studies (Akın and Özsan, 2011; Chentout et al., 2015; Soete et al., 2015). Additionally, in travertine, the relative position of the bedding and the measurement direction has a significant effect on the ultrasonic velocity. Measurements perpendicular to layering have low $V_{p}$ values, while measurements parallel to layering have high values. When the measurement direction is in line with bedding, the travertine laminae provide continuity in the form of columns and as with UCS tests, the wave is conducted faster through the continuous medium. For measurements perpendicular to laminae, the laminae interfaces act like weakness planes and velocity lowers with this effect of cavities (Table 1). When travertine is used as construction material in outdoor spaces, it is exposed to abrasion by natural factors like wind and water, and in situations where it is used as flooring in buildings; they are abraded linked to human activity. The Böhme abrasion losses obtained for travertine zones in the study area vary from $8.98-16 \%$. When the bedding direction of the test specimens are placed perpendicular to the abrasion disc, more abrasion loss was obtained, contrary to Gökçe (2014) (Table 2). When samples are placed in this way, the surface area exposed to abrasion increases linked to the cavities between laminae and the sample is thought to have more interaction with abrasion dust. Within this scope, it is necessary to avoid using travertine slabs cut perpendicular to bedding, especially from T-1 zone, as floor coverings. As a result of 30-cycles of freeze-thaw experiments, all samples had freeze loss value below $1 \%$.

Factors affecting rocks during formation may cause changes to many rock properties like chemical and mineral composition of the rock structure, pore status, density, hardness and strength. Thus, the anisotropic properties of the rock increase. Travertine is a rock group where this effect is observed most. In this study, the mean values for rock properties were used when investigating the anisotropic status of travertine. Firstly, travertine zones were compared considering measurement orientations (Table 6). In terms of uniaxial compressive strength, Los Angeles abrasion resistance, Böhme abrasion loss and point load strength index, the T-4 zone appeared to be better compared to other zones. Additionally, the values obtained parallel $\left(X_{/ /}\right)$and perpendicular $\left(X_{\perp}\right)$ to layering for features investigated in each zone were divided to obtain the anisotropy ratio (R) (Eq. 5). For this investigation the uniaxial compressive strength, point load strength index, ultrasound velocity and Böhme abrasion loss values were chosen for the travertine samples (Table 7). If the $\mathrm{R}$ value is 1 it indicates isotropic behavior, while if it is different to 1 it indicates anisotropic 
behavior. The $R$ values calculated for UCS and $V_{p}$ values were larger than 1 for all zones, while the R values for BAL and $\mathrm{I}_{\mathrm{s}(50)}$ were smaller than 1 . The most pronounced anisotropic behavior appeared to occur for point load strength (Table 7).

$\mathrm{R}=\left(\mathrm{X}_{/ /}\right) /\left(\mathrm{X}_{\perp}\right)(5)$

Table 6

Comparison of rock properties according to zones considering measurement directions

\begin{tabular}{|lll|}
\hline Rock properties & Direction & Zonlarin durumu \\
\hline$\rho_{d}$ & $/ /$ & $\mathrm{T}-3>\mathrm{T}-1>\mathrm{T}-2>\mathrm{T}-4$ \\
& $\perp$ & $\mathrm{T}-2>\mathrm{T}-3>\mathrm{T}-1>\mathrm{T}-4$ \\
& $/ /$ & $\mathrm{T}-4>\mathrm{T}-1>\mathrm{T}-3>\mathrm{T}-2$ \\
\hline UCS & $\perp$ & $\mathrm{T}-1>\mathrm{T}-4>\mathrm{T}-3>\mathrm{T}-2$ \\
& $/ /$ & $\mathrm{T}-4>\mathrm{T}-2=\mathrm{T}-3>\mathrm{T}-1$ \\
$\mathrm{I}_{\mathrm{s}(50)}$ & $\perp$ & $\mathrm{T}-4>\mathrm{T}-1>\mathrm{T}-2=\mathrm{T}-3$ \\
& $/ /$ & $\mathrm{T}-3>\mathrm{T}-2>\mathrm{T}-1>\mathrm{T}-4$ \\
$\mathrm{~V}_{\mathrm{p}}$ & $\perp$ & $\mathrm{T}-4>\mathrm{T}-3>\mathrm{T}-1>\mathrm{T}-2$ \\
& $/ /$ & $\mathrm{T}-4>\mathrm{T}-3>\mathrm{T}-1>\mathrm{T}-2$ \\
\hline $\mathrm{BAL}$ & $\perp$ & $\mathrm{T}-1>\mathrm{T}-4>\mathrm{T}-2>\mathrm{T}-3$ \\
& $/ /$ & $\mathrm{T}-2>\mathrm{T}-3>\mathrm{T}-1=\mathrm{T}-4$ \\
\hline $\mathrm{LA} \mathrm{A}_{500}$ & $\perp$ & $\mathrm{T}-1>\mathrm{T}-2>\mathrm{T}-3>\mathrm{T}-4$ \\
\hline
\end{tabular}

Table 7

Anisotropic behavior linked to direction of travertine layering

\begin{tabular}{|llllll|}
\hline Rock & Anisotropy & \multicolumn{2}{l|}{ Zones } & & \\
\hline properties & ratio & T-1 & T-2 & T-3 & T-4 \\
\hline UCS & R & 1.10 & 1.33 & 1.29 & 1.31 \\
\hline $\mathrm{I}_{\mathrm{s}(50)}$ & $\mathrm{R}$ & 0.43 & 0.57 & 0.63 & 0.27 \\
\hline Vp & $\mathrm{R}$ & 1.15 & 1.34 & 1.35 & 1.18 \\
\hline B.A.K & $\mathrm{R}$ & 0.56 & 0.99 & 0.96 & 0.96 \\
\hline
\end{tabular}

The usability as construction material for travertine zones were assessed in Table 8 according to TS11143 (TSE, 1993). Accordingly, all zones had suitable values in terms of $\rho, A_{w}$ and freeze loss. The UCS values of samples cut parallel to bedding for travertine in T-4 zone were suitable for use as flooring and load-bearing elements, while travertine from the other zones should not be used for these purposes. According to UCS values, both forms of cut from T-4 zone were suitable for decoration and facing, while only the cuts parallel to layering from the other zones were suitable for these purposes. In terms of BAL, travertine from all zones was suitable for decoration and facing. Additionally, only samples cut perpendicular from T-1 zone were unsuitable for flooring and load-bearing. 
Table 8

Usability of travertine zones as construction material according to TS11143

\begin{tabular}{|llllll|}
\hline Parameter & TS11143 & T-1 & T-2 & T-3 & T-4 \\
\hline$\rho\left(\mathrm{g} / \mathrm{cm}^{3}\right)$ & 2.30 & $\sqrt{ }$ & $\sqrt{ }$ & $\sqrt{ }$ & $\sqrt{ }$ \\
\hline $\mathrm{A}_{\mathrm{w}}(\%)$ & $3>$ & $\sqrt{ }$ & $\sqrt{ }$ & $\sqrt{ }$ & $\sqrt{ }$ \\
\hline Frezee loss $(\%)$ & $5>$ & $\sqrt{ }$ & $\sqrt{ }$ & $\sqrt{ }$ & $\sqrt{ }$ \\
\hline UCS (MPa) & $48<$ & $/ /$ & $/ /$ & $/ /$ & $/ / \sqrt{ }$ \\
Flooring and load-bearing & & $\perp$ & $\perp$ & $\perp$ & $\perp$ \\
\hline UCS (MPa) & $30<$ & $/ / \sqrt{ }$ & $/ / \sqrt{ }$ & $/ / \sqrt{ }$ & $/ / \sqrt{ }$ \\
Decoration and facing & & $\perp$ & $\perp$ & $\perp$ & $\perp \sqrt{ }$ \\
\hline BAK (cm ${ }^{3} / 50 \mathrm{~cm}^{2}$ ) & $15>$ & $/ / \sqrt{ }$ & $/ / \sqrt{ }$ & $/ / \sqrt{ }$ & $/ / \sqrt{ }$ \\
Flooring and load-bearing & & $\perp$ & $\perp \sqrt{ }$ & $\perp \sqrt{ }$ & $\perp \sqrt{ }$ \\
\hline BAK (cm ${ }^{3} / 50 \mathrm{~cm}^{2}$ ) & $20>$ & $/ / \sqrt{ }$ & $/ / \sqrt{ }$ & $/ / \sqrt{ }$ & $/ / \sqrt{ }$ \\
Decoration and facing & & $\perp \sqrt{ }$ & $\perp \sqrt{ }$ & $\perp \sqrt{ }$ & $\perp \sqrt{ }$ \\
\hline
\end{tabular}

\section{Conclusions}

In construction projects in interior or exterior spaces, travertine products cut parallel or perpendicular to bedding are commonly used for various purposes. Travertine is sedimentary rock with variable internal structure due to their formation and is generally layered. Travertine products may have different features from quarry to quarry or region to region, while sometimes different appearance and features may occur within a quarry face. In this study, travertine zones identified in a quarry in the Sarıhıdır travertine deposit were comparatively investigated for geological and engineering features and the anisotropic behavior of the engineering parameters was presented. The findings are summarized below:

The $\mathrm{Ba}$ and $\mathrm{Sr}$ values of travertine indicate the source rocks were a mixture of limestone, dolomite, evaporite and ultramafics with epigean character affected by the hypogean environment. There appeared to be textural differences between zones, rather than differences in chemical and mineralogic composition.

The investigated travertine is young crystalline crust type, causing low compressive strength and high abrasion losses. The T-4 zone has clearly better status in terms of these features compared to other zones.

When travertine is cut parallel to bedding, all zones are suitable for decoration and facing purposes. Only samples cut parallel from T-4 zone were useable for flooring and as load-bearing elements. The BAL and UCS values indicate this travertine can be used in interior spaces in terms of lifetime of use.

It has been observed that the cutting direction of the travertine samples has an effect on the relationship between physical and mechanical properties. Samples cut parallel to bedding appeared to provide better results.

As a result, it is very common for travertine products produced from different zones of a quarry to be used side by side for the same purpose in the building. In this case, it is clear that one of them may deteriorate in a shorter time than the other, that the structure will become unusable and require repair. In terms of aesthetics, durability and stability, it should 
be ensured that the products obtained from the travertine quarry, which are visually, physically and mechanically similar to each other, are used side by side.

\section{Declarations}

\section{Acknowledgement}

This study was supported by Yozgat Bozok University Scientific Research Projects Unit with project number 6602aMMF/18-159.

\section{References}

1. Acar H (2003) Doğal taşlarda çatlak tamir ve gözenek dolgu sistemleri. Türkiye IV.Mermer Sempozyumu Bildiriler Kitabı,416-434(in Turkish)

2. Akesson U, Lindqvist JE, Goransson M (2001) Relationship between texture and mechanical properties of granite, Central Sweden, by use of ImageAnalysing Techniques. Bull Eng Geol Environ 60:277-1284

3. Akın M, Özsan A (2011) Evaluation of the long-term durability of yellow travertine using accelerated weathering tests. Bull Eng Geol Environ 70:101-114

4. Altunel E, Hancock PL (1983) Morphology and structural setting of Quaternary travertines at Pamukkale. Turkey Geol J 28:335-346

5. Altunel E (1996) Pamukkale Travertenlerinin Morfolojik Özellikleri, Yaşları ve Neotektonik Önemleri, MTA Dergisi 118, Ankara (in Turkish)

6. Anon (1979) Classification of rocks and soils for engineering geological mapping, Part 1. Rock and soil materials. Bull Int Eng Geol 19:364-371

7. ASTM (2002) American Society for Testing and Materials. Designation: D 2938-95 (Reapproved 2002) Standard Test method for Unconfined Compressive Strength of Intact Rock Core Specimens. ASTM International, 100 Barr Harbor Dr., PO Box C700, West Conshohocken, PA 19428-2959, USA

8. ASTM (2006) Standard test method for resistance to degradation of small-size coarse aggregate by abrasion and impact in the Los Angeles Machine (C131). ASTM International, West Conshohocken

9. Atabey E, Tarhan N, Yusufoğlu H, Canpolat M (1988) Hacıbektaş, Gülşehir, Kalaba,(Nevşehir)-Himmetdede (Kayseri) arasının jeolojisi M.T.A. Rapor No: 8523 (in Turkish)

10. Atabey E (1989) 1/100000 ölçekli açınsama nitelikli Türkiye jeoloji haritaları serisi, Kayseri-H19 paftası, MTA yayını (in Turkish)

11. Ataman G (1972) Ankara'nın güneydoğusundaki granitik-granodiyoritik kütlelerden Cefalık Dağın radyometrik yaşı hakkında önçalışma. Hacettepe Fen Müh Bilim Derg 2:44-49. (in Turkish)

12. Atiker M (1993) Pamukkale, Bilim Teknik Dergisi. 26:308. -): p.495 (in Turkish)

13. Ayaz E, Karacan E (2000) Sivas batısındaki traverten oluşumlarının yapı ve yüzey kaplama taşı olarak kullanılabilirliklerinin incelenmesi. Jeoloji Mühendisliği Dergisi 24(1):87-100. (in Turkish)

14. Ayaz E (2002) Travertenlerde gözlenen morfolojik yapılar ve tabiat varlığı olarak önemleri. Cumhuriyet Üniv Müh Fak Derg Yerbilimleri 19:(2):123-134. (in Turkish)

15. Bieniawski ZT (1975) Point load test in geotechnical practice. Eng Geol 9(1):1-11

16. Bolat S (2011) The Formation, Spread Area and Protection of Travertine in Turkey. Marmara Coğrafya Dergisi 23:389-428. (in Turkish)

Page 13/21 
17. Broch E, Franklin JA (1972) Point-load strength test. Int J Rock Mech Min Sci 9(6):669-697

18. Chafetz HS, Folk RL (1984) Travertines: depositional morphology and the bacterially constructed constituents. J Sed Res 54(1):289-316

19. Chentout M, Alloul B, Rezouk A, Belhai D (2015) Experimental study to evaluate the effect of travertine structure on the physical and mechanical properties of the material. Arab J Geosci 8:8975-8985

20. Chin IR (2007) Travertine: successful and unsuccessful performance, preconceived notions, and mischaracterizations. J ASTM Int 4(7):93-101

21. Çobanoğlu İ, Çelik SB (2012) Determination of strength parameters and quality assessment of Denizli travertines (SW Turkey). Eng Geol 129-130:38-47

22. Deere DV, Miller RL (1966) Engineering Classification and Index Properties of Intact Rock. Department of Civil Engineering, University of Illinois, Urbana, pp 90-101

23. Demirdag S (2009) The effect of using different polymer and cement based materials in pore filling applications on technical parameters of travertine stone. Constr Build Mater 23:522-530

24. Demirdag S (2013) Effects of freezing-thawing and thermal shock cycles on physical and mechanical properties of filled and unfilled travertines. Constr Build Mater 47:1395-1401

25. Ersoy A, Atıcı U, Büyüksağiş IS (2005) The assessment of the specifıc cutting energy in travertine. In: Proceedings of 1 st International Symposium on Travertine, Pamukkale University, pp. 217-223

26. García-del-Cura MA, Benavente D, Martínez JM, Cueto N (2012) Sedimentary structures and physical properties of travertine and carbonate tufa building stone. Constr Build Mater 28:456-467

27. Gökçe MV (2014) The effects of bedding directions on abrasion resistance in travertine rocks. Turkish J Earth Sci 24:196-207

28. Gökçe MV, İnce İ, Fener M, Taşkıran T, Kayabali K (2016) The effects of freeze-thaw (F-T) cycles on the Gödene travertine used in historical structures in Konya (Turkey). Cold Reg Sci Technol 127:65-75

29. Guo L, Riding R (1998) Hot-spring travertine facies and sequences, late Pleistocene, Rapolano Terme, Italy. Sedimentology 45(1):163-180

30. Isık EC, Ozkahraman HT (2010) An economic solution to high quality travertine filling. Constr Build Mater 24:2619-2627

31. ISRM (2007) The Complete ISRM Suggested Methods for Rock Characterization, Testing and Monitoring: 19742006, R. Ulusay and J.A. Hudson (eds.), Suggested Medhods Prepared by Commissions on Testing Methods, International Society for Rock Mechanics, Compilation Arranged by the ISRM Turkish National Group, Kozan Ofset, Ankara, Turkey, pp. 628

32. İnan N (1985) Antalya travertenlerinin oluşumu ve özellikleri. Jeoloji Mühendisleri Dergisi 24:31-37

33. Kahraman S (2009) The effect of rock classes on the relation between uniaxial compressive strength and point load index. Bull Eng Geol Environ 68:345-353

34. Kaplan İK (2010) Budaklar ve Manlar formasyonlarındaki travertenlerin mühendislik özellikleri (Eskipazar, Karabük). Master Thesis, 101 p., Ankara University, Ankara, Turkey (in Turkish)

35. Khanlari G, Naseri F (2017) The prediction of compressive strength of travertines with special reference to laminaeorientation using index tests. Geopersia 7(2):279-299

36. Koçak i (2020) Sarıhıdır manganese mineralization related to travertine, Central Anatolian Volcanic Province, Turkey. Geodin Acta 20:11-24

37. Koçyiğit A, Doğan U (2016) Strike-slip neotectonic regime and related structures in the Cappadocia region: a case study in the Salanda basin, Central Anatolia, Turkey. Turkish J Earth Sci 25(5):393-417

Page $14 / 21$ 
38. Kolay E, Baser T (2017) The effect of the textural characteristics on the engineering properties of the basalts from Yozgat region, Turkey. J Geol Soc India 90:102-110

39. Moos AV, Quervain FDe (1948) Technische Gesteinkunde. Verlag Birkhauser, Basel

40. Ozcelik Y, Yilmazkaya E (2011) The effect of the rock anisotropy on the efficiency of diamond wire cutting machines. Int J Rock Mech Min 48:626-636

41. Pentecost A (2005) Travertine. Springer-Verlag, Berlin, Heidelberg

42. Sengun N, Demirdag S, Ugur I, Akbay D, Altindag R (2015) Assessment of the physical and mechanical variations of some travertines depend on the bedding plane orientation under physical weathering conditions. Constr Build Mater 98:641-648

43. Seymen I (1981) Kaman (Kırşehir) Dolayında Kırşehir Masifınin Stratigrafısi ve metamorfızması. Türkiye Jeol Kur Bült 24/2:101-108

44. Soete J, Kleipool LM, Claes H, Claes S, Hamaeker H, Kele S, Özkul M, Foubert A, Reijmer JJG, Swennen R (2015) Acoustic properties in travertines and their relation to porosity and pore types. Mar Pet Geol 59:320-335

45. Teboul PA, Durlet C, Gaucher EC, Virgone A, Girard JP, Curie J, Camoin GF (2016) Origins of elements building travertine and tufa: New perspectives provided by isotopic and geochemical tracers. Sediment Geol 334:97-114

46. TSE (1993) Travertine-Used As Building and Facing Stone (TS11143). Institute of Turkish Standards, Ankara

47. TSE (2017) Natural stone test methods: Determination of the abrasion resistance (TS EN 14157). Institute of Turkish Standards, Ankara

48. TSE (2011) Natural stone test methods: Determination of frost resistance (TS EN 12371). Institute of Turkish Standards, Ankara

49. Török Á, Vásárhelyi B (2010) The influence of fabric and water content on selected rock mechanical parameters of travertine, examples from Hungary. Eng Geol 115:237-245

50. Tugrul A, Zarif IH (1999) Correlation of Mineralogical and Textural Characteristics with Engineering Properties of Selected Granitic Rocks from Turkey. Eng Geol 51:303-317

51. Tutuş M (2009) Statistical analysis of physico-mechanical characteristics on some marbles situated in Çukurova region. MSc, Çukurova University, Adana, Turkey

52. Uz B, Öztaş T, Esenli F, Özdamar Ş (2001) Düzköy-Düzağaç (Ulus-Bartın) Traverten Oluşumlarının Jeolojisi, Petrografısi ve Mermer Açısından Değerlendirilmesi. Türkiye III.Mermer Sempozyumu (MERSEM'2001) Bildiriler Kitabı, Afyon (in Turkish)

53. Wilson RL (1979) Building Stones of Downtown Chattanooga. University of Tennessee at Chattanooga Geology Department, Chattanooga, TN, USA

\section{Figures}




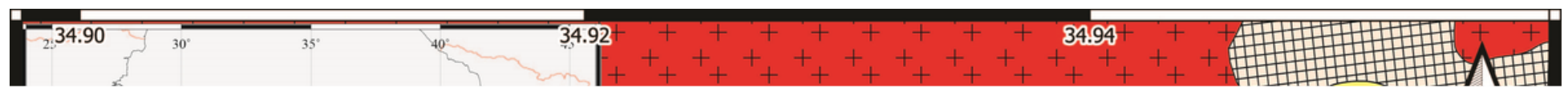

\section{Figure 1}

Location and geological map of the study area (adapted from Atabey, E., 1989) 


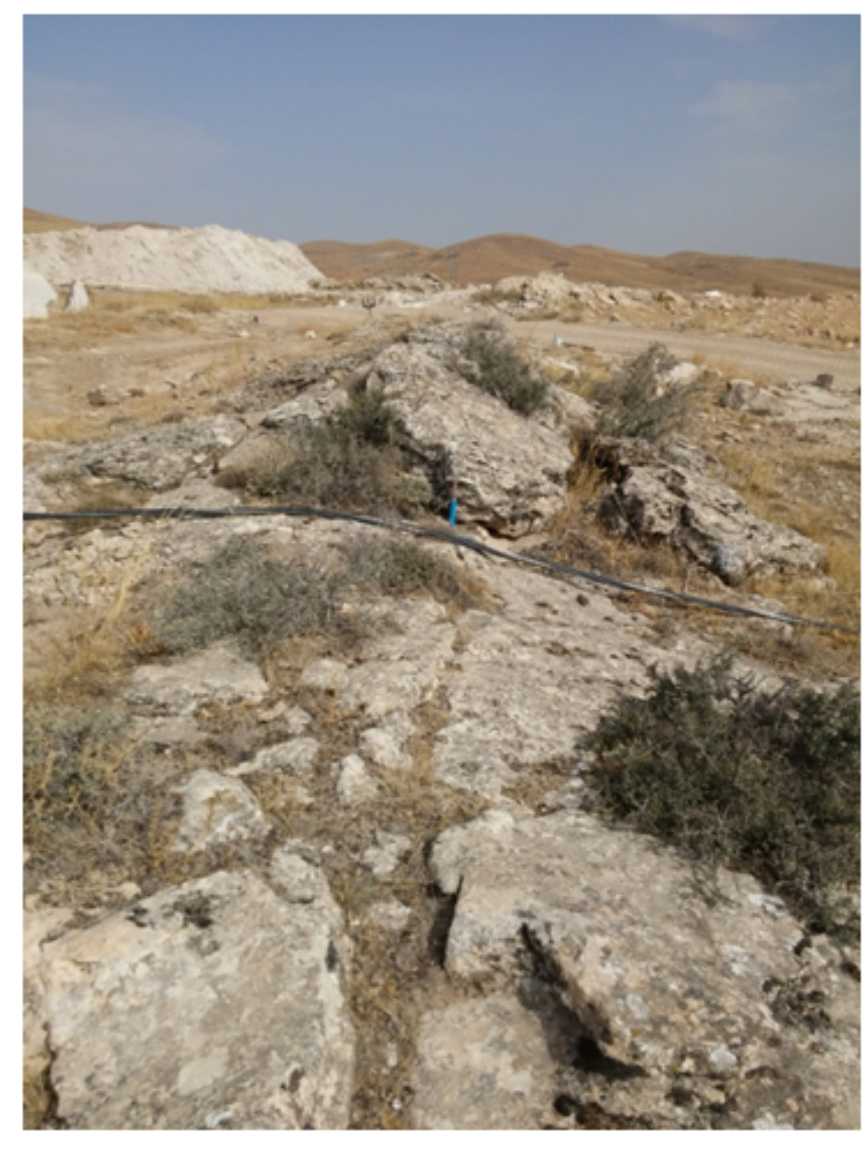

(a)

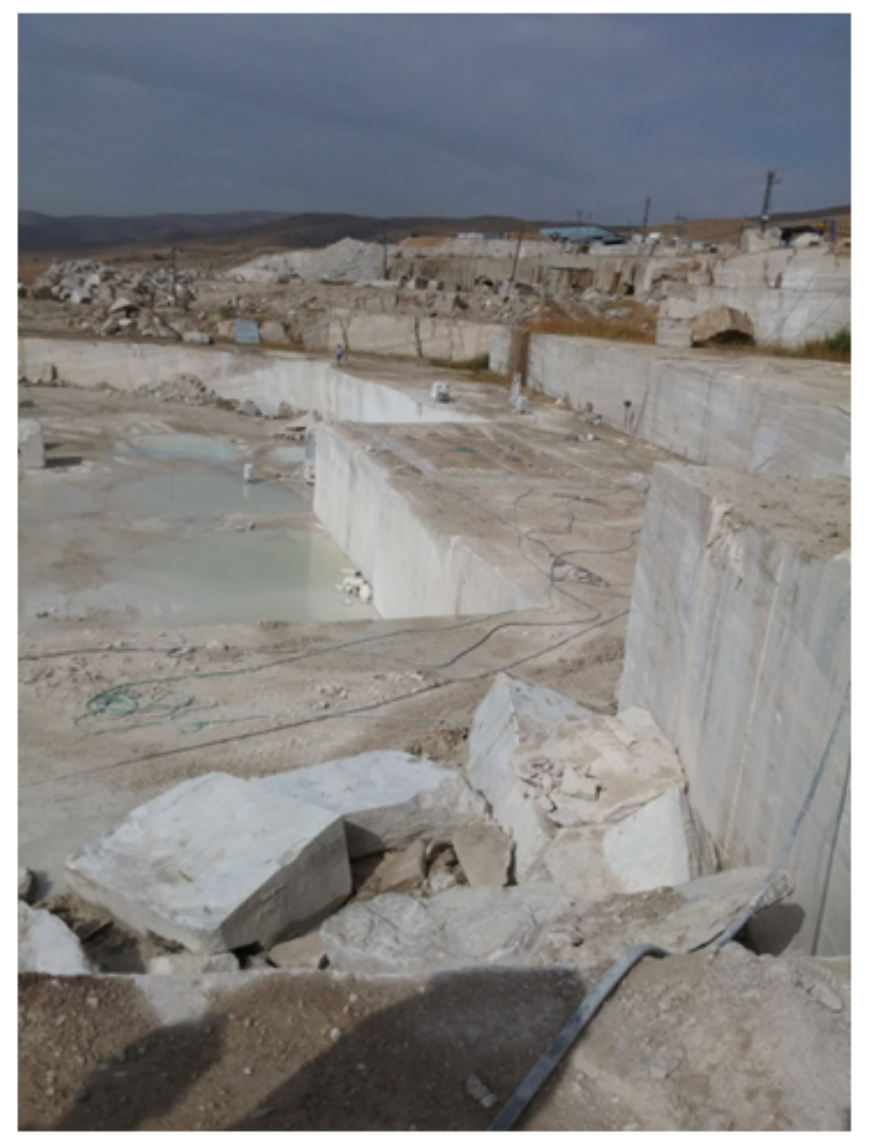

(b)

\section{Figure 2}

Appearance of fissure ridge-type Sarıhıdır travertine in the field (a) and in the quarry (b) 


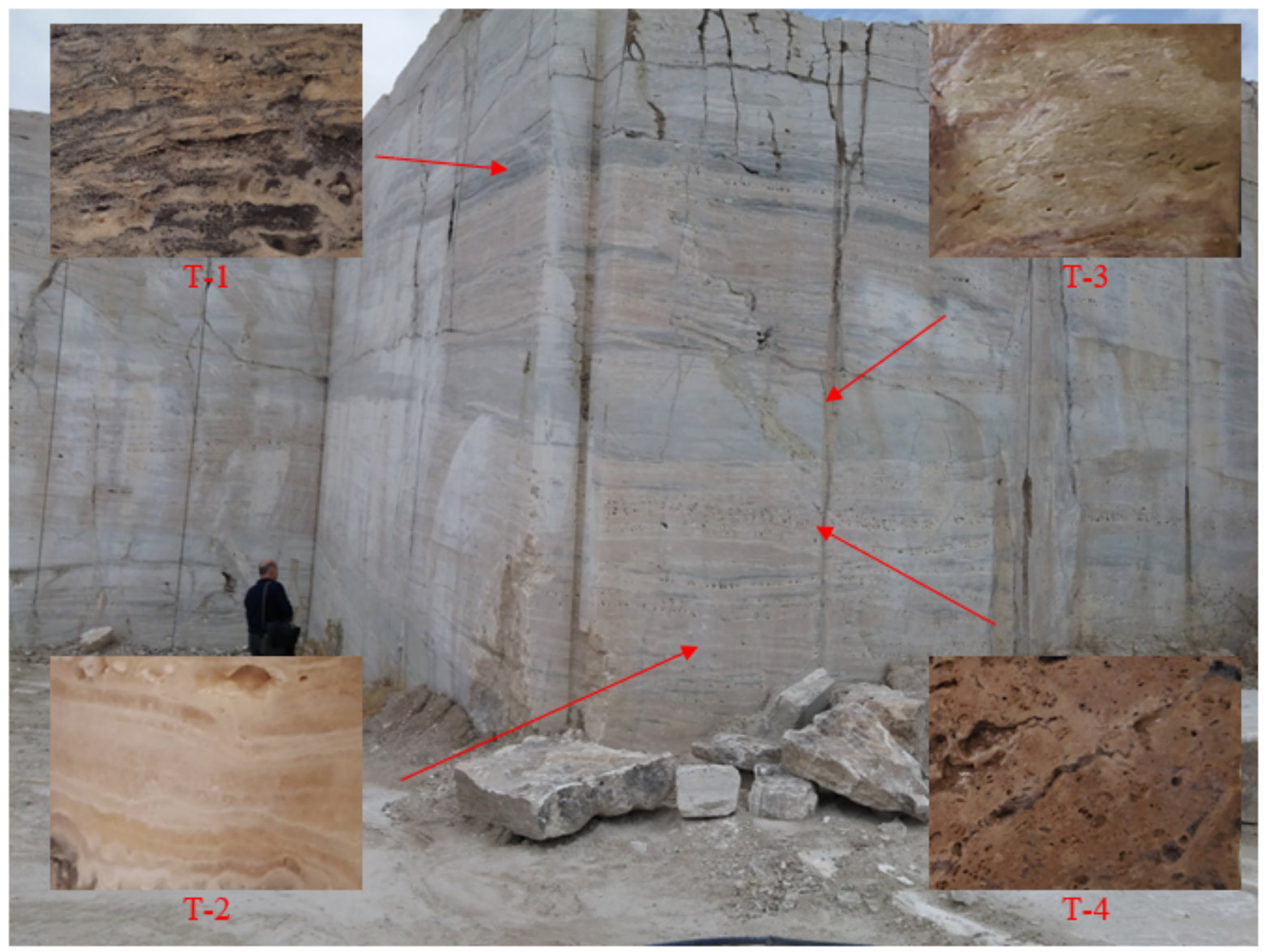

Figure 3

$\mathrm{T}-1, \mathrm{~T}-2, \mathrm{~T}-3$ and $\mathrm{T}-4$ zones in the travertine quarry 


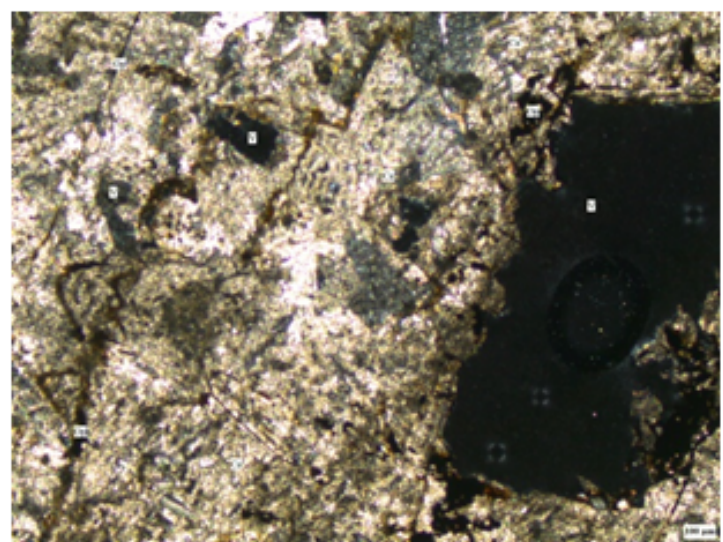

T-1

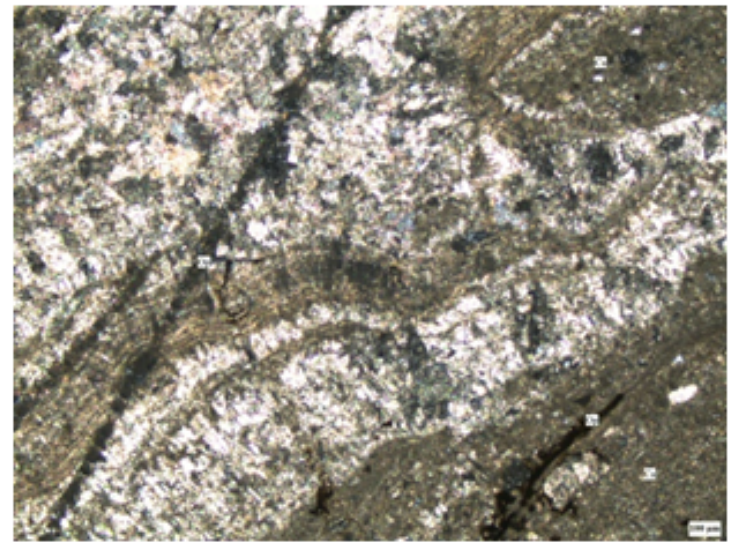

T-3

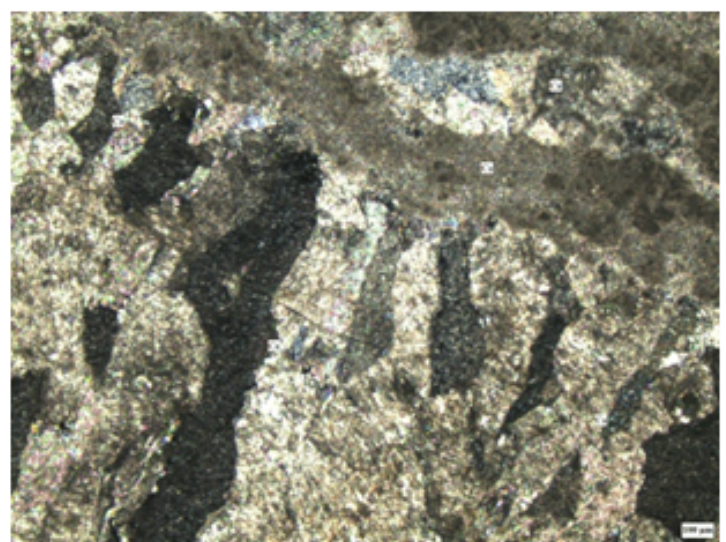

T-2

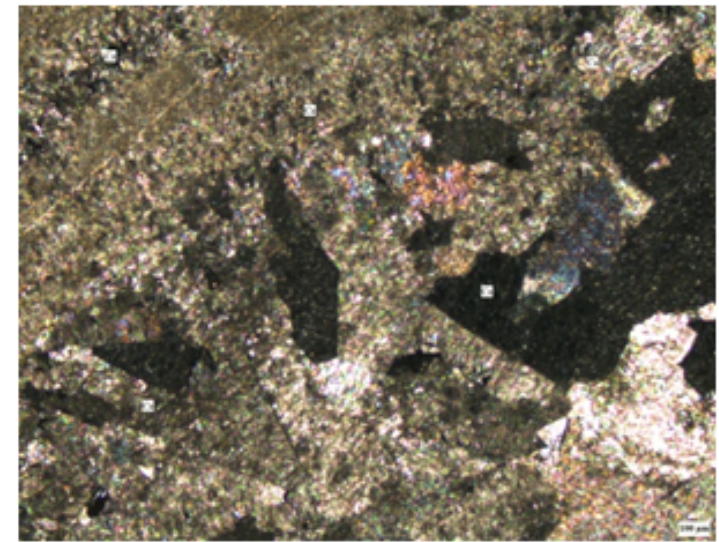

T-4

Figure 4

Appearance of travertine under cross-polarized light

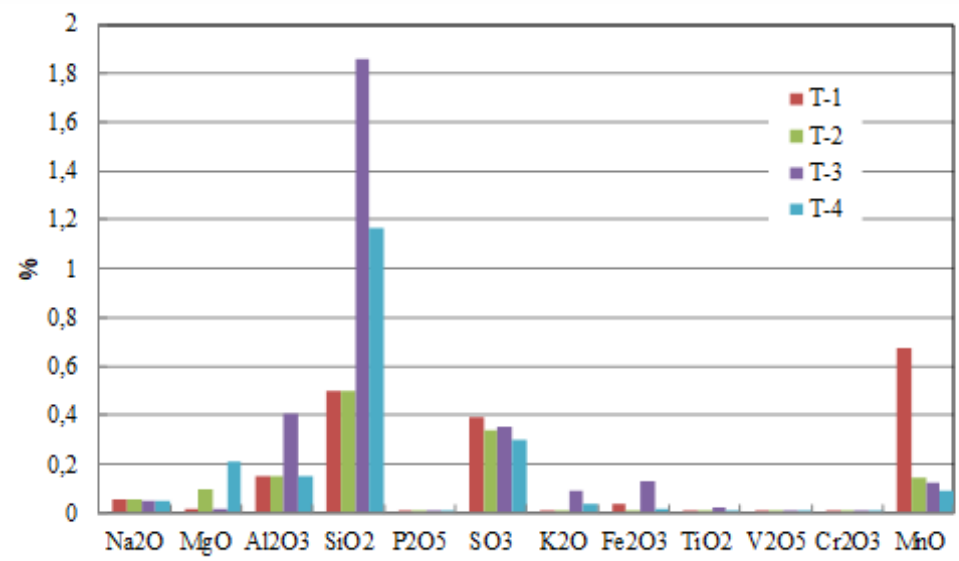

(a)

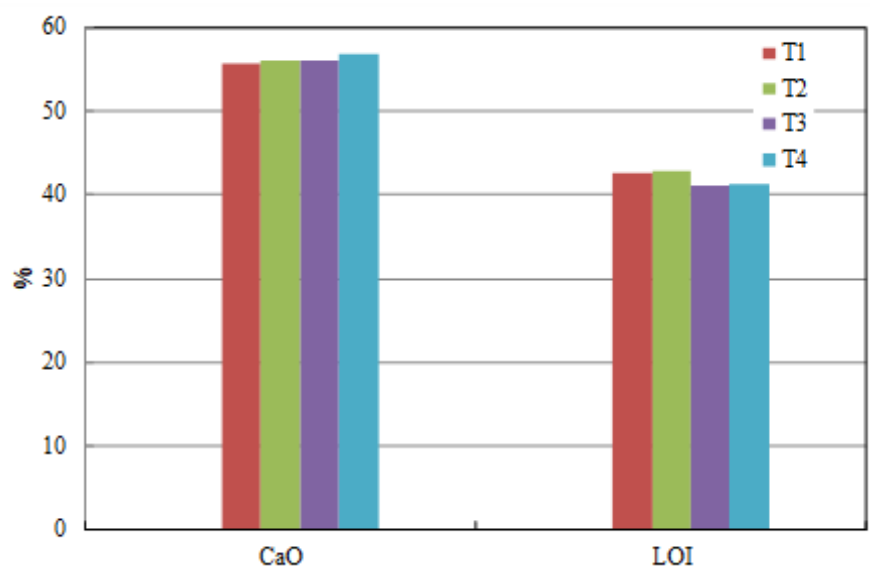

(b)

Figure 5

Basic oxides (a, b) and loss on ignition (LOI) (b) values for travertine samples 


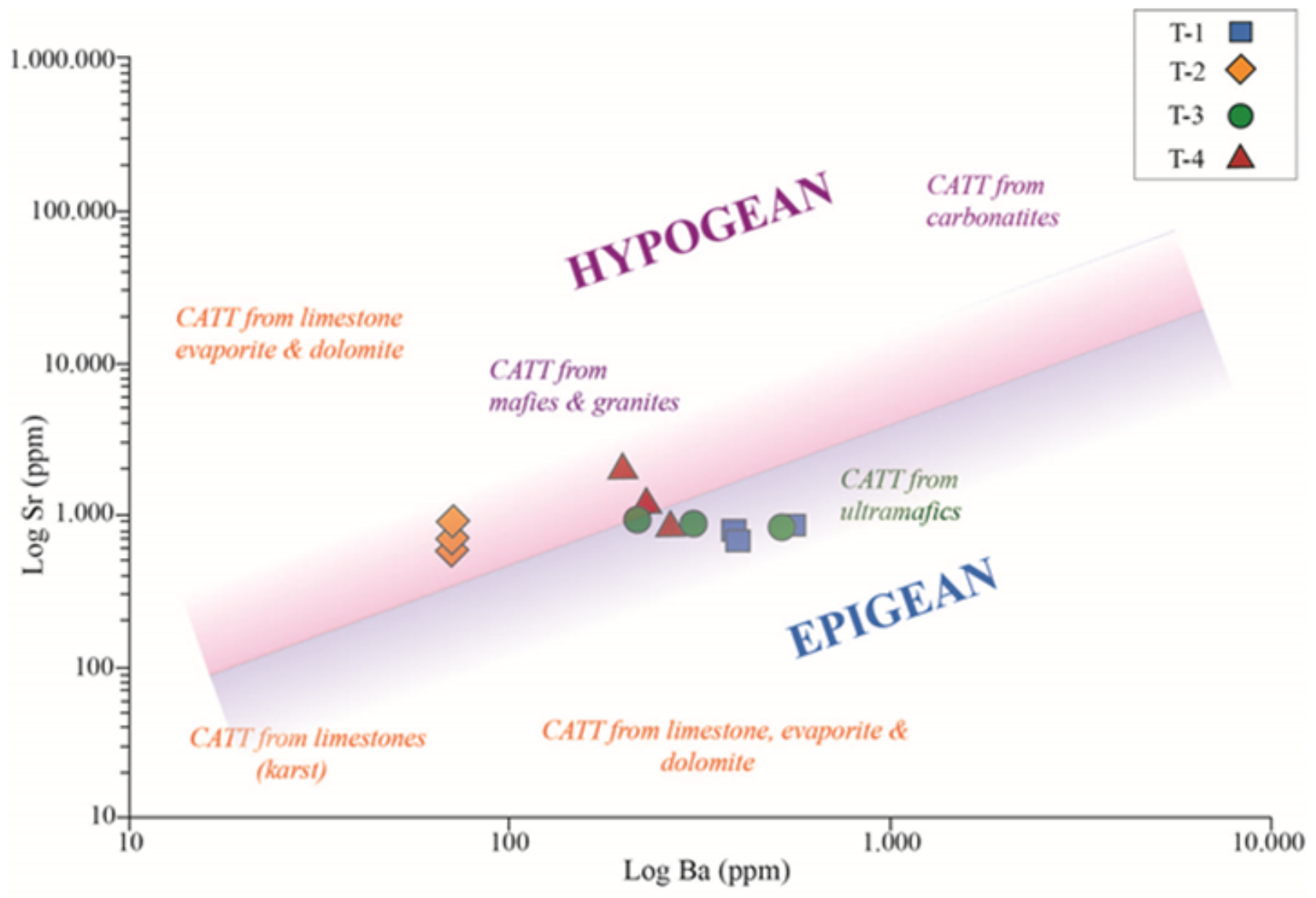

Figure 6

Log Ba against log Sr diagram for Sarıhıdır travertine (Teboul et al., 2016)

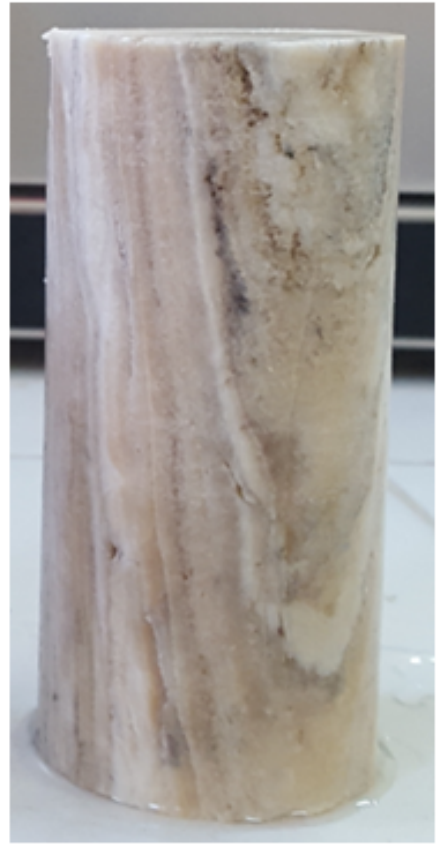

(a)

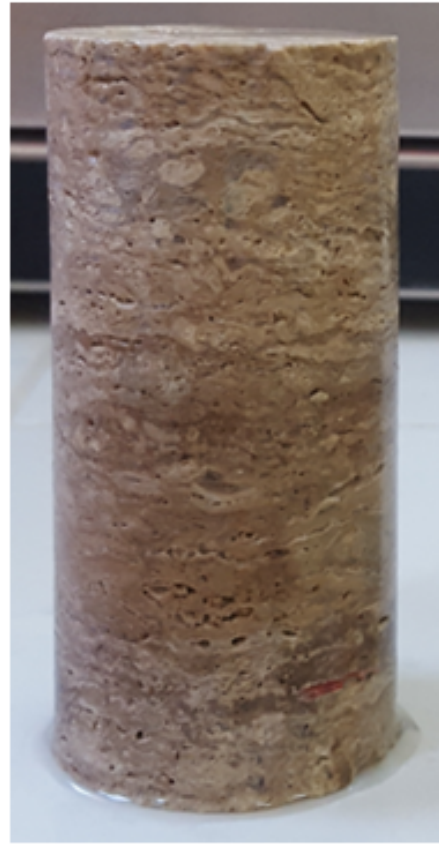

(b) 
Figure 7

Cylindrical experimental samples prepared with long axis parallel (//) (a) and perpendicular $(\perp)(b)$ to layering

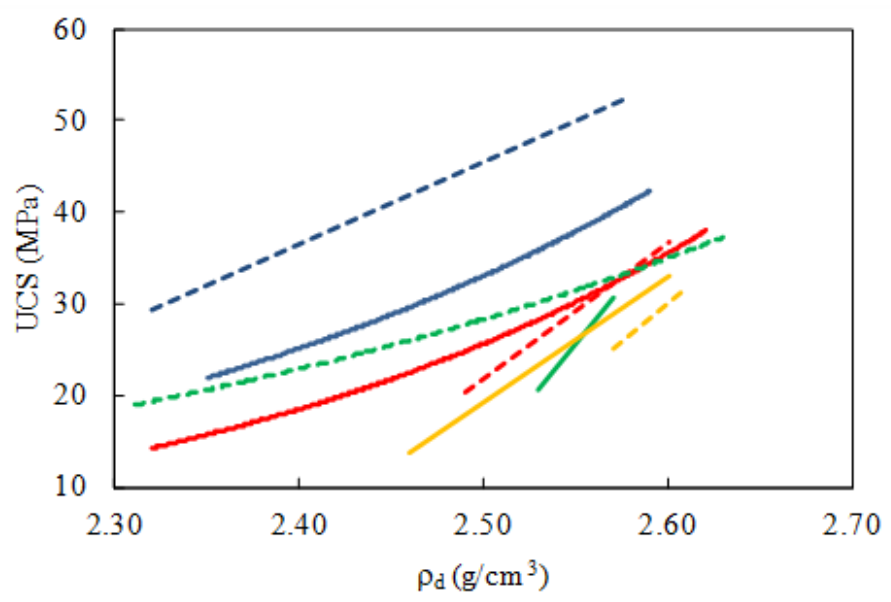

(a)

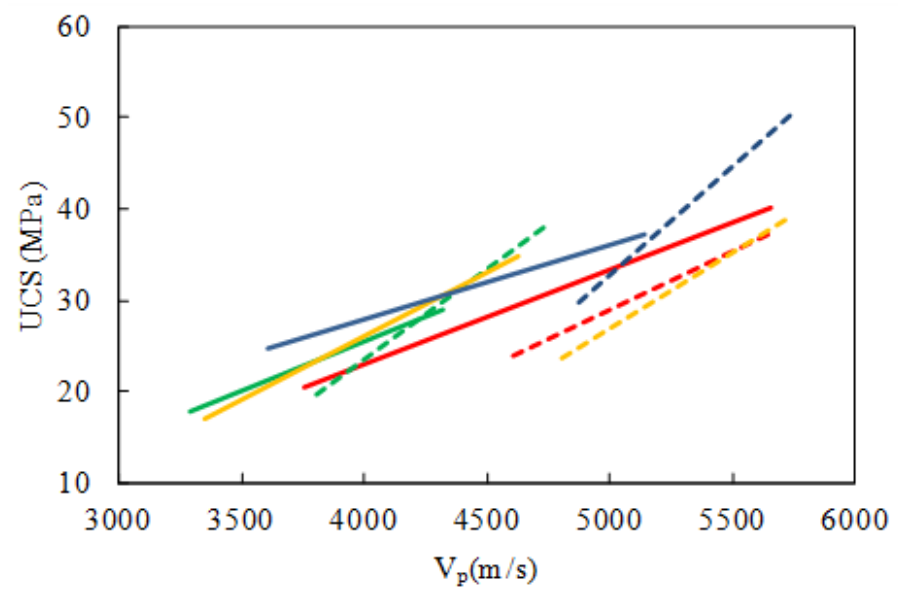

(c)

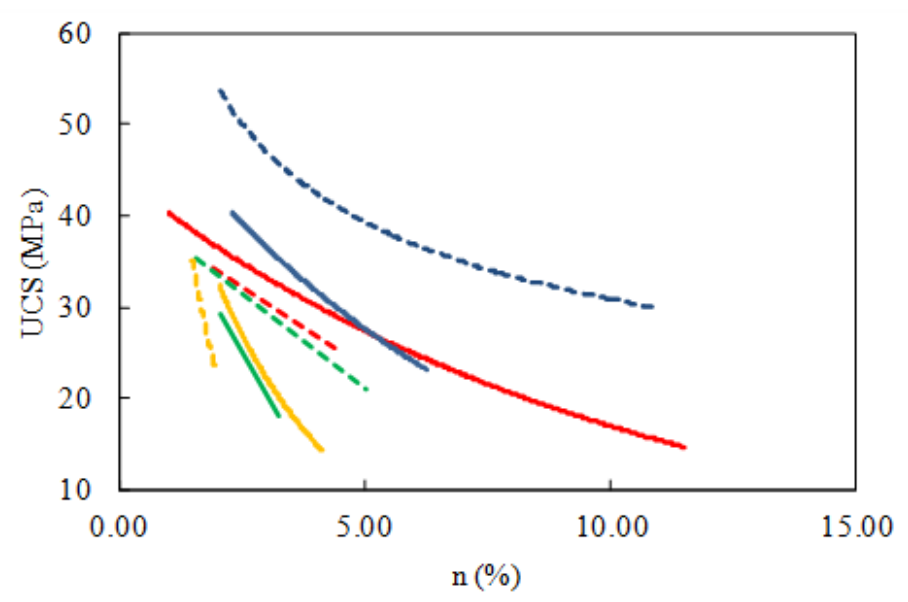

(b)

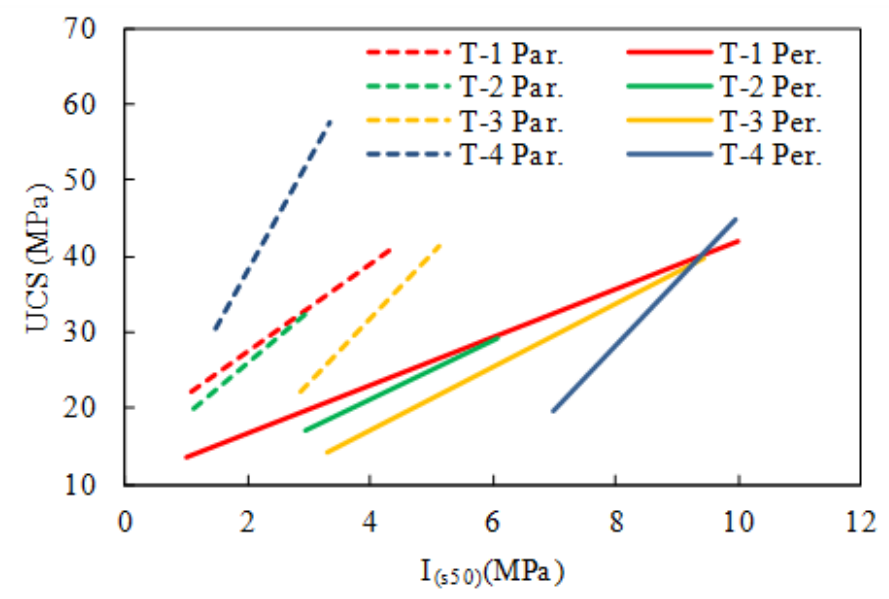

(d)

\section{Figure 8}

Simple regression curves for UCS values with $r_{d}(a), n(b), V_{p}(c)$ and $I_{s(50)}$ values for travertine (Par.: Parallel, Per.: Perpendicular) 